\title{
Cytotoxic Tumour-Selective 1,5-Diaryl-3-Oxo-1,4-Pentadienes Mounted on a Piperidine Ring
}

\author{
Praveen K. Roayapalley ${ }^{1, *(\mathbb{D}}$, Hiroshi Sakagami ${ }^{2}{ }^{(\mathbb{D}}$, Keitaro Satoh ${ }^{2}$, Shigeru Amano ${ }^{2}$, Kenjiro Bandow ${ }^{2}{ }^{(1)}$, \\ Renato J. Aguilera ${ }^{3}$, Karla G. Cano Hernandez ${ }^{3}$, Austre Y. Schiaffino Bustamante ${ }^{3}$, Stephen G. Dimmock ${ }^{4}$, \\ Rajendra K. Sharma ${ }^{5}$, Umashankar Das ${ }^{1}$ and Jonathan R. Dimmock ${ }^{1}$
}

Citation: Roayapalley, P.K.; Sakagami, H.; Satoh, K.; Amano, S.; Bandow, K.; Aguilera, R.J.; Hernandez, K.G.C.; Schiaffino Bustamante, A.Y.; Dimmock, S.G.; Sharma, R.K.; et al. Cytotoxic Tumour-Selective 1,5-Diaryl-3-Oxo-1,4-Pentadienes Mounted on a Piperidine Ring. Medicines 2021, 8, 78. https:// doi.org/10.3390/medicines8120078

Academic Editor: Tadayuki Akagi

Received: 1 October 2021

Accepted: 14 December 2021

Published: 16 December 2021

Publisher's Note: MDPI stays neutral with regard to jurisdictional claims in published maps and institutional affiliations.

Copyright: (c) 2021 by the authors. Licensee MDPI, Basel, Switzerland. This article is an open access article distributed under the terms and conditions of the Creative Commons Attribution (CC BY) license (https:/ / creativecommons.org/licenses/by/ $4.0 /)$
1 Drug Discovery and Development Research Group, University of Saskatchewan, Saskatoon, SK S7N 5E5, Canada; umashankar.usask@gmail.com (U.D.); jr.dimmock@usask.ca (J.R.D.)

2 School of Dentistry, Meikai University, Sakado, Saitama 350-0283, Japan; sakagami@dent.meikai.ac.jp (H.S.); k-satoh@dent.asahi-u.ac.jp (K.S.); shigerua@dent.meikai.ac.jp (S.A.); kbando@dent.meikai.ac.jp (K.B.)

3 Department of Biological Sciences and Border Biomedical Research Center, The University of Texas at El Paso, El Paso, TX 79968-0519, USA; raguilera@utep.edu (R.J.A.);

Karla.CanoHernandez@UTSouthwestern.edu (K.G.C.H.); aschiaf@emory.edu (A.Y.S.B.)

4 Department of Finance, National University of Singapore, Singapore 119245, Singapore; dimmock@nus.edu.sg

5 Department of Pathology and Laboratory Medicine, College of Medicine, University of Saskatchewan, Saskatoon, SK S7N 0W8, Canada; rajendra.sharma@usask.ca

* Correspondence: rpraveen.sp@usask.ca

Abstract: A series of 3,5-bis(benzylidene)-4-piperidones 2a-u were prepared as candidate cytotoxic agents. In general, the compounds are highly toxic to human gingival carcinoma (Ca9-22), human squamous carcinoma-2 (HSC-2) and human squamous carcinoma-4 (HSC-4) neoplasms, but less so towards non-malignant human gingival fibroblast (HGF), human periodontal ligament fibroblast (HPLF) and human pulp cells (HPC), thereby demonstrating tumour-selective toxicity. A further study revealed that most of the compounds in series 2 were more toxic to the human Colo-205 adenocarcinoma cell line (Colo-205), human HT29 colorectal adenocarcinoma cells (HT-29) and human CEM lymphoid cells (CEM) neoplasms than towards non-malignant human foreskin Hs27 fibroblast line (Hs27) cells. The potency of the cytotoxins towards the six malignant cell lines increased as the sigma and sigma star values of the aryl substituents rose. Attempts to condense various aryl aldehydes with 2,2,6,6-tetramethyl-4-piperidone led to the isolation of some 1,5-diaryl-1,4-pentadien3 -ones. The highest specificity for oral cancer cells was displayed by $\mathbf{2 e}$ and $\mathbf{2 r}$. In the case of $\mathbf{2 r}$, its selective toxicity exceeded that of doxorubicin and melphalan. The enones $\mathbf{2 k}, \mathbf{m}$, o have the highest SI values towards colon cancer and leukemic cells. Both $\mathbf{2 e}, \mathbf{r}$ inhibited mitosis and increased the subG1 population (with a transient increase in G2/M phase cells). Slight activation of caspase-3, based on the cleavage of poly(ADP-ribose)polymerase (PARP) and procaspase 3, was detected.

Keywords: 4-piperidones; unsaturated ketones; cytotoxicity; quantitative structure-activity relationships (QSAR); Western blot; cell cycle inhibition

\section{Introduction}

A major interest in our laboratories is the design, synthesis and antineoplastic evaluation of 1,5-diaryl-3-oxo-1,4-pentadienes mounted on a variety of scaffolds, which give rise to series 1 (Figure 1). Most previous studies of structurally-related compounds were conducted without or with very low numbers of normal cells at the same time as cancer cell lines, making it difficult to compare tumor-specificity between compounds [1-10]. Among these previous 10 papers, three papers are from our research group [5-7]. Our group used four human oral squamous cell carcinoma cell lines (Ca9-22, HSC-2, HSC3, HSC-4) with three human normal oral mesenchymal cells (HGF, HPLF, HPC) [5,6] and human CRL1790 (non-malignant colon cells) [10]. Other groups have used human 
HepG2 (hepatocellular carcinoma), HeLa (cervical cancer), K562 (erythroleukemia), THP1 (monocytic leukemia), LO2 (hepatocyte cell line) [1], HCT-116 (colorectal carcinoma), MCF-7 (breast adenocarcinoma) [2], HepG2, MCF-7 [3], GCIY (stomach cancer), HCT-116, DLD1 (colorectal adenocarcinoma), SW680 (colon cancer), A549 (lung carcinoma), PK1 (pig kidney epithelial cells), ACHN (renal adenocarcinoma), HUH7 (immortal cell line composed of epithelial-like, tumorigenic cells), OVK18 (ovarian cancer), MCF-7, 8505c (thyroid carcinomas), G361 (melanoma) and PC3 (prostate cancer) [4], as well as A2780 (ovarian cancer), ACHN, HCT-116 and PC-3 and U937-GTB (leukemic monocyte lymphoma) cell lines [8], B16 (murine melanoma) and L1210 (murine lymphoma) cells [7] and P-388 (murine leukemia) [8] cell lines. Thus, very few previous studies have used human oral cancer cells. Furthermore, most of these papers, except [1], have not used appropriate normal control cells derived from the same tissues at the same time. By comparing the cytotoxicity of a total 21 compounds $(\mathbf{2 a}-\mathbf{2} \mathbf{u})$ against oral malignant and non-malignant cells, with two reference compounds, the present study demonstrated that $2 \mathbf{r}$ showed the highest tumor-specificity. One of the purposes of the present study is to prepare compounds which are easy to synthesize and have selective toxicity against oral cancer, for use in a series of our research projects for dental application [11,12].

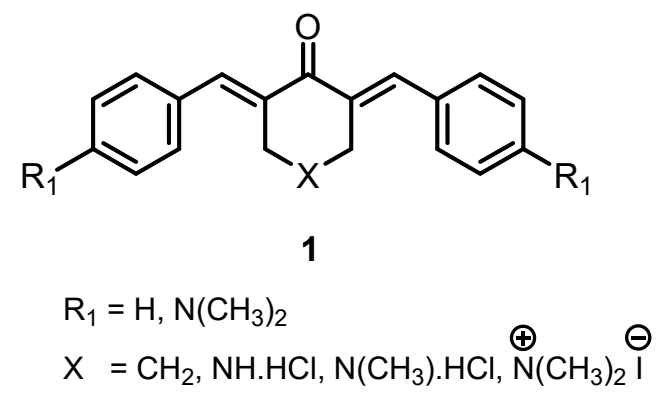

Figure 1. Initial series of cytotoxins 1.

Recently, we have concentrated our efforts on 4-piperidones which have the general structure $\mathbf{2}$ as indicated in Figure 2. First, their bioactivity is likely due to reactivity with cellular thiols. However, these dienones do not react readily, if at all, with amino and hydroxyl groups $[13,14]$, which are present in nucleic acids. Thus, the possibility of these unsaturated ketones causing genotoxic effects, which are present in a number of anticancer drugs, is reduced. An important goal of this investigation was to find compounds which are more cytotoxic to neoplasms than towards non-malignant cells. If this objective is achieved, then investigations were planned in order to find correlations between various physicochemical substituents and the magnitude of antineoplastic potencies. Such cytotoxic warheads could be converted into more complex candidate anticancer agents through suitable molecular modifications. For example, the placement of a group onto the piperidyl nitrogen atom, which contains a positively charged phosphorous atom, may have a greater attraction to tumour mitochondria than to mitochondria of non-malignant cells [15].

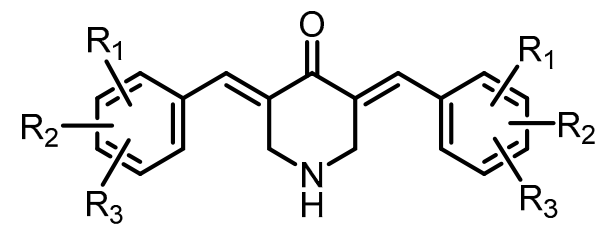

2

Figure 2. The general structure of the compounds in series 2 . The aryl substituents are indicated in Tables 1,2 and 4. 


\section{Materials and Methods}

\subsection{Synthesis of Compounds}

${ }^{1} \mathrm{H}$ and ${ }^{13} \mathrm{C}$ Nuclear Magnetic Resonance (NMR) spectra were obtained using a Bruker $500 \mathrm{MHz}$ spectrometer equipped with a Broad Band Observe (BBO) probe. Chemical shifts $(\delta)$ are reported in ppm. Melting points were determined using a DigiMelt-MPA 160 instrument and are uncorrected. The mass spectra were obtained using a Jeol JMS-T100 GCv Accu tof-gcV4G instrument.

The general procedure for the syntheses of $\mathbf{2 a}-\mathbf{u}$ is as follows [16]. The aryl aldehyde $(11.46 \mathrm{mmol})$ and 4-piperidone hydrochloride monohydrate $(5.60 \mathrm{mmol})$ were added to glacial acetic acid $(15 \mathrm{~mL})$ and stirred for five minutes. Dry hydrogen chloride gas was passed through this mixture for about $45 \mathrm{~min}$ until a clear solution was obtained. The reaction mixture was stirred at room temperature for $24 \mathrm{~h}$, and the precipitate formed was collected by filtration. The crude product was treated with a mixture of $10 \mathrm{~mL}$ of saturated aqueous potassium carbonate solution $(25 \% w / v)$ and $10 \mathrm{~mL}$ of acetone and stirred at room temperature for $45 \mathrm{~min}$. The free base was collected by filtration, washed with ice-cold water and dried. The compounds were taken for the next reaction with the acid chloride without further purification.

The percentage yields, melting points, ${ }^{1} \mathrm{H}$ and ${ }^{13} \mathrm{C}$ NMR spectra and mass spectra of $2 \mathbf{a}-\mathbf{u}$ are given in the Supplemental section of this paper.

The general method adopted for the formation of 3a-d (Figure 3 ) is as follows. The aryl aldehyde $(2.64 \mathrm{mmol})$ and 2,2,6,6-tetramethyl-4-piperidone $(1.28 \mathrm{mmol})$ were dissolved in $20 \mathrm{~mL}$ of methanol (3a) and absolute ethanol (3b-d) and stirred at room temperature for $5 \mathrm{~min}$. Sodium metal $(4.5 \mathrm{mmol})$ was added slowly to the reaction mixture at $0{ }^{\circ} \mathrm{C}$. After all the sodium metal dissolved, the reaction mixture was stirred at room temperature for $1 \mathrm{~h}$ and then heated to $50-55^{\circ} \mathrm{C}$ overnight. The reaction mixture was cooled to $5-10{ }^{\circ} \mathrm{C}$, and $5 \mathrm{~mL} 6 \mathrm{~N}$ hydrochloric acid was slowly added. The organic solvent was completely evaporated, and the residue was extracted with ethyl acetate. The organic extract was dried over anhydrous sodium sulfate and concentrated to attain the crude compound, which was purified by column chromatography using silica gel-60 (0.040-0.063 mm, 230-400 mesh) and $5 \%$ ethyl acetate in hexane as the mobile phase.

The percentage yields, melting points, ${ }^{1} \mathrm{H}$ NMR spectra and mass spectra of $\mathbf{3 a}-\mathbf{d}$ and ${ }^{13} \mathrm{C}$ NMR spectra of $\mathbf{3 b} \mathbf{b}-\mathbf{d}$ are presented in the Supplemental section of this article.

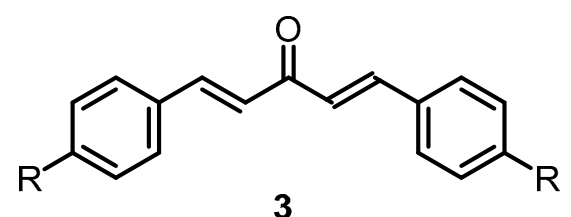
$\mathrm{a}: \mathrm{R}=\mathrm{OCH}_{3}$
$\mathrm{C}: \mathrm{R}=\mathrm{Cl}$
$b: \mathrm{R}=\mathrm{H}$
$d: R=F$

Figure 3. Products of the reaction between 2,2,6,6-tetramethyl-4-piperidone and various aryl aldehydes, a: $\mathrm{R}=\mathrm{OCH}_{3} ; \mathbf{b}: \mathrm{R}=\mathrm{H} ; \mathrm{c}: \mathrm{R}=\mathrm{Cl} ; \mathrm{d}: \mathrm{R}=\mathrm{F}$.

\subsection{QSAR Studies}

The sigma/sigma star $\left(\sigma / \sigma^{*}\right)$, pi $(\pi)$ and Molar Refractivity (MR) values used in the QSAR studies were taken from a reference source $[17,18]$. The linear and semilogarithmic plots were undertaken using a Statistical Package for the Social Sciences (SPSS) package [19].

\subsection{Cytotoxicity Assays}

A literature procedure was followed when evaluating series 2 against Ca9-22, HSC-2, HSC-4, HGF, HPLF and HPC cells except that the cells were incubated with the compounds for $48 \mathrm{~h}$, not $24 \mathrm{~h}$ [20]. In brief, varying amounts of material were incubated at $37^{\circ} \mathrm{C}$ with the neoplastic and non-malignant cells in Dulbecco's Modified Eagle Medium (DMEM) 
supplemented with $10 \%$ heat-inactivated fetal bovine serum. The cell viability was determined by the 3-(4,5-dimethylthiazol-2-yl)-2,5-diphenyl-2H-tetrazolium bromide (MTT) method, as described previously [20]. We have previously reported that doxorubicininduced potent cytotoxicity against human normal oral epithelial cells such as human oral keratinocyte (HOK) and primary human gingival epithelial cells (HGEP) [21]. Therefore, we used human normal oral mesenchymal cells, rather than epithelial cells, to develop new anticancer drugs that have much lower keratinocyte toxicity [22]. Furthermore, HGF and Ca9-22 were derived from gingival tissue.

The method used in the evaluation of series 2 against Colo205, HT-29, CRM and Hs27 cells has been described previously [23,24]. In brief, the cells were cultured in DMEM (Colo205, HT29 and Hs27) or RPMI -1640 (CEM) media supplemented with 10\% heatinactivated fetal bovine serum. Different concentrations of the compounds were added to the cell cultures and then viability was measured using the Differential DNA Staining (DNS) assay after $24 \mathrm{~h}$ incubation $[23,24]$. After analysis of the effects of a range of concentrations of the compounds, the $\mathrm{CC}_{50}$ value (the concentration of the compound to kill $50 \%$ of the cells) was determined. After subtracting the percentage of cell death caused by the solvent (DMSO-treated cells), a linear interpolation equation was used to determine the $\mathrm{CC}_{50}$ values $[24,25]$.

The induction of apoptosis in Ca9-22 cells was evaluated through morphological changes, and the Western blot and cell cycle analysis has been described previously [26]. In brief, cell morphology was checked periodically under the light microscope (EVOS FL, ThermoFisher Scientific, Waltham, MA, USA). Western blot analysis was performed as described previously [27]. Briefly, cells were collected and lysed, and protein samples of cell lysates $(9 \mu \mathrm{g})$ were applied to SDS-polyacrylamide gel electrophoresis. After electrophoresis, the separated proteins were transferred onto a PVDF filter. The blots were blocked in skim milk and then probed for $120 \mathrm{~min}$ with a primary antibody cocktail (1:250) from an Apoptosis Western Blot Cocktail kit (Abcam, Cambridge, UK). The cocktail included anti-caspase 3, anti-PARP and anti-actin antibodies. The blots were washed and then probed with a horseradish peroxidase-conjugated secondary antibody cocktail (1:100) from the kit. The cocktail included anti-mouse and anti-rabbit secondary antibodies. The immunoreactivities were determined using Amersham ECL Select (Cytiva, Tokyo, Japan). Images were acquired using the ChemiDoc MP System and Image Lab 4.1 software (Bio-Rad Laboratories, Hercules, CA, USA).

For cell cycle analysis, cells were fixed with $1 \%$ paraformaldehyde, treated with $0.2 \mathrm{mg} / \mathrm{mL}$ RNase A, stained with $0.01 \%$ propidium iodide, filtered through Falcon ${ }^{\circledR}$ cell strainers $(40 \mu \mathrm{M})$ (Corning, NY, USA), subjected to cell sorting and then analyzed (SH800 Series; SONY Imaging Products and Solutions Inc., Kanagawa, Japan).

\section{Results}

The compounds in series 2 were prepared by the reaction of 4-piperidone with various aryl aldehydes. These dienones were screened against human Ca9-22, HSC-2 and HSC-4 oral squamous carcinomas (Table 1), as well as human gingival fibroblast (HGF), human periodontal ligament fibroblasts (HPLF) and human pulp cells (HPC) (Tables 2 and 3). In addition, the evaluation of series 2 was also assessed against human Colo205 and HT29 colon cancers, CEM lymphoid leukemia cells and human Hs27 foreskin fibroblasts (Tables 4 and 5).

Investigations were implemented to find some of the ways that two representative compounds exert their cytotoxic potencies. Control Ca9-22 cells show a homogenous population (Figure 4A), with no detectable amount of cleaved products of PARP and procaspase-3 (substrates of caspase 3) (lane 1 in Figure 5) and low subG1 population levels (consisting of fragmented DNA) (1.7\%) (Table 6). When Ca9-22 cells were treated for $24 \mathrm{~h}$ with $1 \mu \mathrm{M}$ actinomycin $\mathrm{D}$ (reference compound), apparent induction of apoptosis markers such as cell shrinkage (Figure 4B), cleavage of PARP and procaspase (lane 2 in Figure 5) and subG1 population accumulation (Table 6) were confirmed. Pictures of the morphologies of 
the cells before the cell harvest are shown in the lower panel of Supplementary Figure S2. Reproducible morphological changes were confirmed.
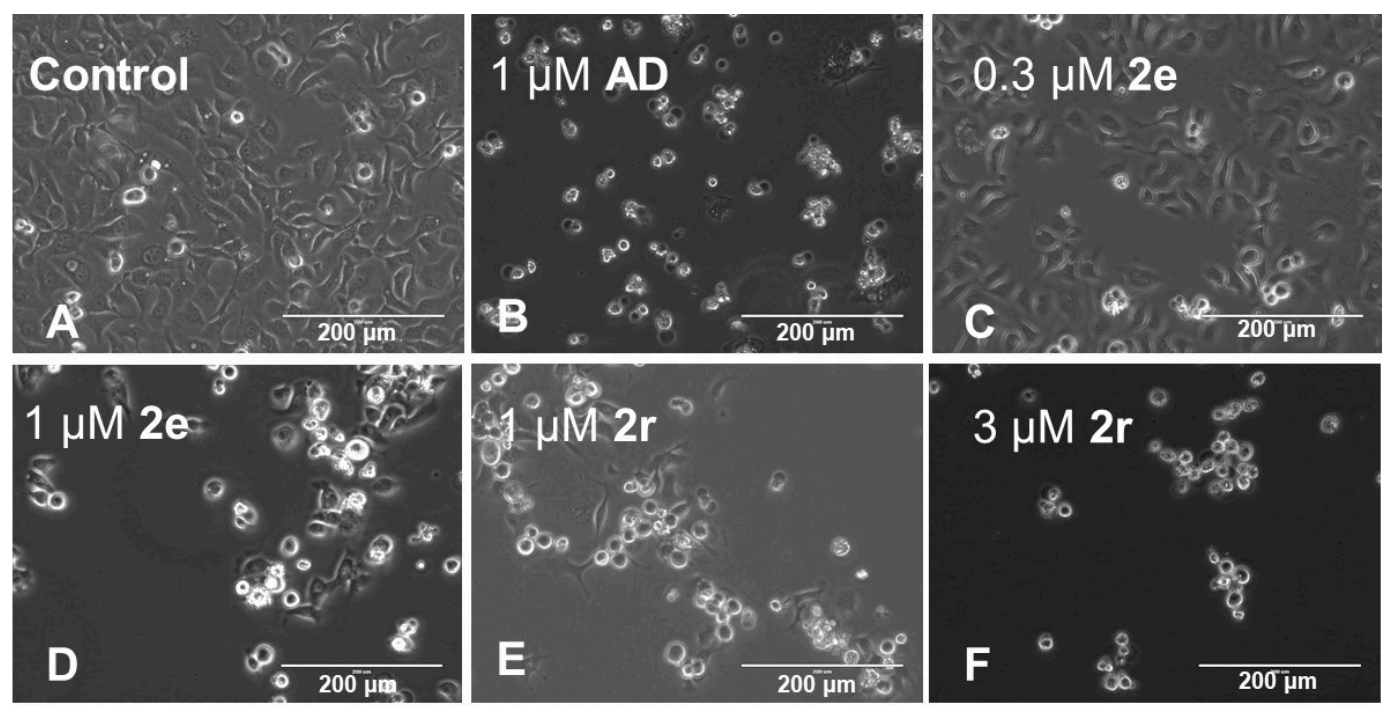

Figure 4. Morphological change induced in Ca9-22 cells after $24 \mathrm{~h}$ incubation without (control) (A); with $1 \mu \mathrm{M}$ actinomycin $\mathrm{D}$ (AD, reference compound) (B); with 0.3 and $1 \mu \mathrm{M}$ of $2 \mathbf{e}(\mathbf{C}, \mathbf{D})$; and with 1 and $3 \mu \mathrm{M}$ of $2 \mathbf{r}$ (E,F). Actinomycin D induced apoptotic bodies, whereas $2 \mathbf{e}$ and $\mathbf{2} \mathbf{r}$ induced cell spreading at lower concentrations and cell shrinkage at higher concentrations (The scale bar is $200 \mu \mathrm{m}$ ). This point was clarified by Western blot analysis (Figure 5) and cell cycle analysis (Table 6).

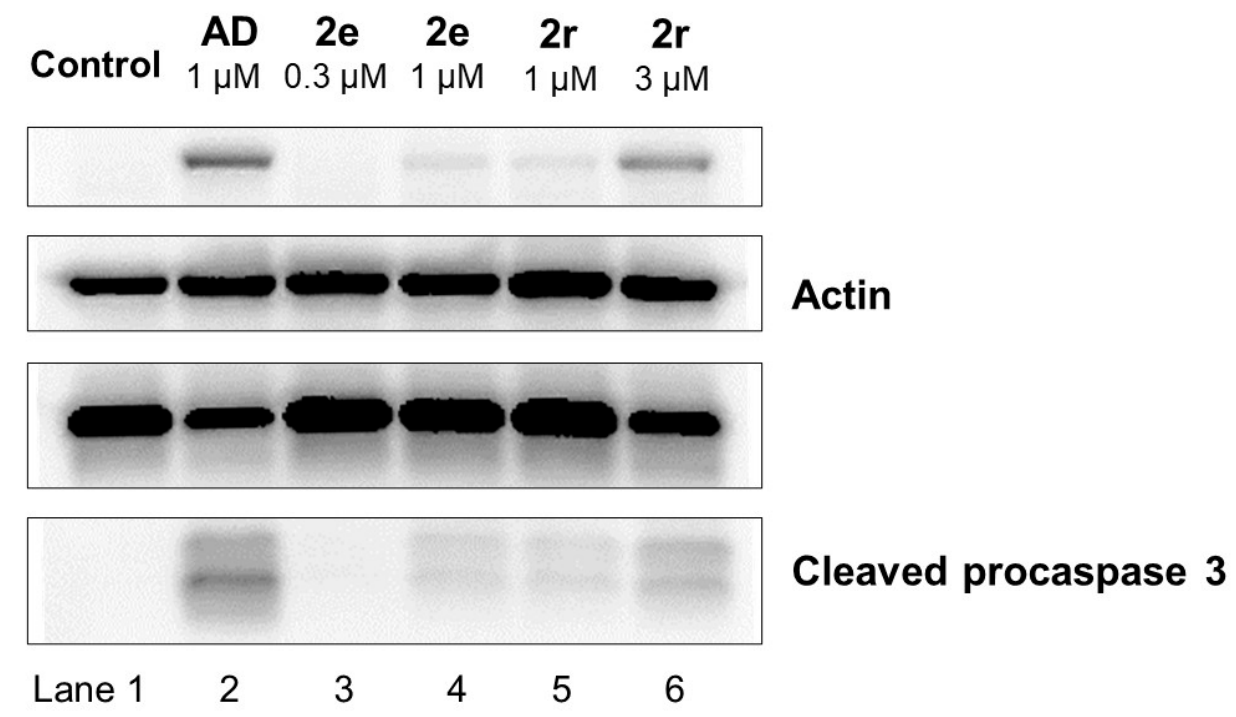

Figure 5. Western blot analysis of 2e, r. Ca9-22 cells were incubated for $24 \mathrm{~h}$ without (control) and with the indicated concentrations of samples, and cell lysates were prepared as described in Materials and Methods. Protein $(9 \mu \mathrm{g})$ was loaded to each lane for Western blot analysis, and images after long exposure with contrast adjustment are presented. Raw data of stained gel and images after short and long exposure (without and with contrast adjustment) are shown in Supplementary Figure S1.

When cells were treated with a lower concentration of $2 \mathbf{e}(0.3 \mu \mathrm{M})$, slight cell speading (Figure 4C), an undetectable level of cleaved products (lane 3 in Figure 5) and minor levels of subG1 (2.2\%) (Table 6) were observed. When $2 \mathrm{e}$ concentration was increased to $1 \mu \mathrm{M}$, cell shrinkage (Figure 4D), cleavage products (lane 4 in Figure 5) and subG1 accumulation (9.3\%) were more apparent. A similar magnitude of changes in these markers was observed in the cells treated with $2 \mathrm{r}(1 \mu \mathrm{M})$ (Figure $4 \mathrm{E}$, lane 5 in Figure 5 and Table 6$)$. It should be 
noted that the percentage of G2/M was the highest in the cells treated with $2 \mathbf{e}(1 \mu \mathrm{M})$ and $2 \mathbf{r}(1 \mu \mathrm{M})(50.2$ and $57.9 \%$, respectively) (Table 6$)$. When $2 \mathbf{r}$ concentration was increased up to $3 \mu \mathrm{M}$, more marked cell shrinkage (Figure $4 \mathrm{~F}$ ), caspase- 3 activation (cleavage of PARP and procaspase) (lane 6 in Figure 5) and subG1 accumulation (24.5\%), along with a decline in G2/M (29.1\%) (Table 6), were observed. These data suggest that $2 \mathbf{e}$ and $2 \mathbf{r}$ induced G2/M accumulation and then subG1 or G1 accumulation.

In an attempt to prepare 3,5-bis(4-methoxybenzylidene)-2,2,6,6-tetramethyl-4-piperidone, the product obtained was 1,5-bis(4-methoxyphenyl)-3-oxo-1,4-pentadiene. This reaction was shown to be a general method for preparing these acyclic derivatives, and a reaction mechanism for their formation was proposed.

\section{Discussion}

The compounds in series 2 were prepared by acidic catalysis of a number of aryl aldehydes with 4-piperidone using a literature procedure [16]. The average yield is $72 \%$. All of the compounds in series 2 were characterized by ${ }^{1} \mathrm{H}$ and ${ }^{13} \mathrm{C}$ NMR spectroscopy as well as mass spectrometry, and these details may be found in the Supplemental Section of this article.

A number of different groups are present in the aryl rings of $\mathbf{2 a - u}$ as indicated in Table 1. In particular, methoxy and fluoro groups are present since they have been incorporated into a number of potent cytotoxins prepared in our laboratory $[10,28,29]$.

Table 1. Evaluation of 2a-u against Ca9-22, HSC-2 and HSC-4 human oral squamous cell carcinoma cell lines.

\begin{tabular}{|c|c|c|c|c|c|c|c|c|c|}
\hline \multicolumn{10}{|c|}{ Human Oral Squamous Cell Carcinoma Cell Lines } \\
\hline & & Ca9-22 & & HSC-2 & & HSC-4 & & Average & \\
\hline Compound & $\mathrm{R}$ & $\mathrm{CC}_{50}(\mu \mathrm{M})^{\mathrm{a}}$ & $\mathrm{SI}{ }^{b}$ & $\mathrm{CC}_{50}(\mu \mathrm{M})^{\mathrm{a}}$ & $\mathrm{SI}^{\mathrm{b}}$ & $\mathrm{CC}_{50}(\mu \mathrm{M})^{\mathrm{a}}$ & $\mathrm{SI}^{\mathrm{b}}$ & $\mathrm{CC}_{50}(\mu \mathrm{M})^{\mathrm{a}}$ & $\mathrm{SI}^{\mathrm{b}}$ \\
\hline $2 \mathbf{a}^{c}$ & $\mathrm{H}$ & $0.27 \pm 0.03$ & 58.1 & $0.31 \pm 0.05$ & 50.6 & $0.41 \pm 0.13$ & 38.3 & $0.33 \pm 0.07$ & 49.0 \\
\hline $2 b$ & $2-\mathrm{OCH}_{3}$ & $0.13 \pm 0.02$ & 40.3 & $0.33 \pm 0.09$ & 15.9 & $0.50 \pm 0.04$ & 10.5 & $0.32 \pm 0.18$ & 22.2 \\
\hline $2 c^{d}$ & $3-\mathrm{OCH}_{3}$ & $0.10 \pm 0.03$ & 18.2 & $0.02 \pm 0.04$ & 91.0 & $0.12 \pm 0.02$ & 15.2 & $0.08 \pm 0.01$ & 41.5 \\
\hline $2 d^{e}$ & $4-\mathrm{OCH}_{3}$ & $3.13 \pm 0.40$ & 17.8 & $7.97 \pm 0.68$ & 6.98 & $6.86 \pm 0.77$ & 8.10 & $5.99 \pm 2.53$ & 11.0 \\
\hline $2 e^{e}$ & $3,4-\left(\mathrm{OCH}_{3}\right)_{2}$ & $0.02 \pm 0.01$ & 136 & $0.24 \pm 0.04$ & 11.3 & $0.07 \pm 0.00$ & 38.9 & $0.11 \pm 0.11$ & 62.1 \\
\hline $2 f^{d}$ & $2,5-\left(\mathrm{OCH}_{3}\right)_{2}$ & $0.06 \pm 0.01$ & 23.3 & $0.17 \pm 0.07$ & 8.23 & $0.18 \pm 0.08$ & 7.78 & $0.14 \pm 0.07$ & 13.1 \\
\hline $2 g^{e}$ & $2,4,6-\left(\mathrm{OCH}_{3}\right)_{3}$ & $6.90 \pm 0.30$ & 5.00 & $7.95 \pm 0.70$ & 4.34 & $8.93 \pm 0.75$ & 3.86 & $7.93 \pm 1.08$ & 4.40 \\
\hline $2 h^{e}$ & $3,4,5-\left(\mathrm{OCH}_{3}\right)_{3}$ & $0.04 \pm 0.01$ & 24.3 & $0.08 \pm 0.01$ & 12.1 & $0.11 \pm 0.03$ & 8.82 & $0.08 \pm 0.04$ & 15.1 \\
\hline $2 i^{d}$ & $3,4-\mathrm{OCH}_{2} \mathrm{O}$ & $0.16 \pm 0.07$ & 102 & $0.53 \pm 0.12$ & 30.8 & $0.71 \pm 0.22$ & 23.0 & $0.47 \pm 0.28$ & 51.9 \\
\hline $2 \mathrm{j}^{\mathrm{e}}$ & $2-\mathrm{F}$ & $0.16 \pm 0.04$ & 21.4 & $0.33 \pm 0.23$ & 10.4 & $0.23 \pm 0.01$ & 14.9 & $0.24 \pm 0.09$ & 15.6 \\
\hline $2 k$ & $3-\mathrm{F}$ & $0.07 \pm 0.01$ & 26.3 & $0.13 \pm 0.03$ & 14.2 & $0.12 \pm 0.05$ & 15.3 & $0.11 \pm 0.03$ & 18.6 \\
\hline $21^{c}$ & $4-\mathrm{F}$ & $0.14 \pm 0.06$ & 32.9 & $0.94 \pm 1.28$ & 4.90 & $0.16 \pm 0.02$ & 28.8 & $0.41 \pm 0.45$ & 22.2 \\
\hline $2 m$ & $3,4-\mathrm{F}_{2}$ & $0.06 \pm 0.03$ & 41.2 & $0.14 \pm 0.05$ & 17.6 & $0.07 \pm 0.01$ & 35.3 & $0.09 \pm 0.04$ & 31.4 \\
\hline $2 n$ & $2,6-\mathrm{F}_{2}$ & $0.17 \pm 0.02$ & 24.5 & $0.40 \pm 0.10$ & 10.4 & $0.31 \pm 0.21$ & 13.5 & $0.29 \pm 0.11$ & 16.1 \\
\hline 20 & $2-\mathrm{CH}_{3}$ & $0.45 \pm 0.04$ & 26.4 & $0.79 \pm 0.19$ & 15.1 & $1.05 \pm 0.34$ & 11.3 & $0.76 \pm 0.30$ & 17.6 \\
\hline $2 p$ & $2-\mathrm{NO}_{2}$ & $0.13 \pm 0.01$ & 20.8 & $0.31 \pm 0.06$ & 8.71 & $0.30 \pm 0.15$ & 9.00 & $0.25 \pm 0.10$ & 12.8 \\
\hline $2 q$ & $3-\mathrm{OCH}_{3}, 4-\mathrm{OH}$ & $0.61 \pm 0.23$ & 13.4 & $0.61 \pm 0.08$ & 13.4 & $0.63 \pm 0.16$ & 13.0 & $0.62 \pm 0.01$ & 13.3 \\
\hline $2 r$ & $3-\mathrm{OH}, 4-\mathrm{OCH}_{3}$ & $0.23 \pm 0.01$ & 214 & $0.29 \pm 0.06$ & 170 & $0.31 \pm 0.12$ & 159 & $0.28 \pm 0.04$ & 181 \\
\hline $2 s^{e}$ & $4-\mathrm{OH}$ & $1.67 \pm 0.13$ & 54.1 & $2.52 \pm 0.19$ & 35.9 & $3.20 \pm 0.58$ & 28.3 & $2.46 \pm 0.77$ & 39.4 \\
\hline $2 t^{d}$ & $3-\mathrm{OH}$ & $0.18 \pm 0.01$ & 28.2 & $0.21 \pm 0.01$ & 24.1 & $0.20 \pm 0.04$ & 25.4 & $0.20 \pm 0.01$ & 25.9 \\
\hline $2 \mathbf{u}$ & $2-\mathrm{Cl}$ & $0.10 \pm 0.04$ & 49.6 & $0.16 \pm 0.02$ & 31.0 & $0.25 \pm 0.12$ & 19.8 & $0.17 \pm 0.08$ & 33.5 \\
\hline \multicolumn{2}{|c|}{ Doxorubicin } & $0.24 \pm 0.04$ & 31.5 & $0.07 \pm 0.00$ & 108 & $0.08 \pm 0.01$ & 94.5 & $0.13 \pm 0.10$ & 78.0 \\
\hline \multicolumn{2}{|c|}{ Melphalan } & $27.4 \pm 6.40$ & 6.30 & $13.9 \pm 3.80$ & 12.4 & $14.4 \pm 1.70$ & 12.0 & $18.6 \pm 7.63$ & 10.2 \\
\hline
\end{tabular}

${ }^{a}$ The $\mathrm{CC}_{50}$ values are the concentrations of compounds required to kill $50 \%$ of the cells. ${ }^{\mathrm{b}}$ The letters SI refer to the selectivity index. The SI figures are the ratios of the average $\mathrm{CC}_{50}$ value of the compounds towards non-malignant HGF, HPLF and HPC cells (Table 2 ) and the $\mathrm{CC}_{50}$ figure of a compound against a specific neoplastic cell line. ${ }^{\mathrm{c}}$ Reference [16], ${ }^{\mathrm{d}}$ Reference [7], ${ }^{\mathrm{e}}$ Reference [30].

The cytotoxic properties of the compounds in series 2 were evaluated in two independent laboratories. In the first place, 2a-u were screened against human Ca9-22, HSC-2 and HSC-4 squamous cell carcinomas, and the results are portrayed in Table 1. No less than $86 \%$ of the $\mathrm{CC}_{50}$ figures are submicromolar and $14 \%$ of the compounds have double-digit nanomolar $\mathrm{CC}_{50}$ values. The dienones with average $\mathrm{CC}_{50}$ values of less than $0.1 \mu \mathrm{M}$ are as 
follows (with aryl substituents in parentheses): $\mathbf{2} \mathbf{c}\left[3-\mathrm{OCH}_{3}\right], \mathbf{2} \mathbf{h}\left[3,4,5-\left(\mathrm{OCH}_{3}\right)_{3}\right]$ and $\mathbf{2 m}$ $\left[3,4-\mathrm{F}_{2}\right]$. These three compounds are equipotent with doxorubicin and are much more toxic than melphalan.

There are significant differences between several pairs of structural isomers. Thus, the mean $\mathrm{CC}_{50}$ value of $2 \mathrm{c}$ is 75 times lower than the figure for $\mathbf{2 d}$. A similar comparison between $2 \mathrm{~g}$ and $2 \mathrm{~h}$ indicates a 99 -fold difference in potency, while the mean $\mathrm{CC}_{50}$ figure for $2 \mathrm{t}$ is 12 times lower than the value for $\mathbf{2 s}$.

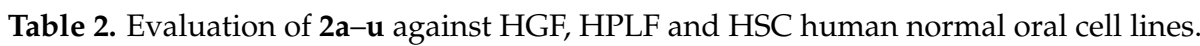

\begin{tabular}{|c|c|c|c|c|c|c|}
\hline \multicolumn{7}{|c|}{ Human Normal Oral Cell Lines } \\
\hline & & HGF & HPLF & HPC & Average & PSE $^{b}$ \\
\hline Compound & $\mathrm{R}$ & $\mathrm{CC}_{50}(\mu \mathrm{M})^{\mathrm{a}}$ & $\mathrm{CC}_{50}(\mu \mathrm{M})^{\mathrm{a}}$ & $\mathrm{CC}_{50}(\mu \mathrm{M})^{\mathrm{a}}$ & $\mathrm{CC}_{50}(\mu \mathrm{M})^{\mathrm{a}}$ & \\
\hline $2 a^{c}$ & $\mathrm{H}$ & $7.78 \pm 0.85$ & $17.0 \pm 2.29$ & $22.3 \pm 2.61$ & $15.7 \pm 7.33$ & 14,849 \\
\hline $2 b$ & $2-\mathrm{OCH}_{3}$ & $2.11 \pm 0.13$ & $4.84 \pm 3.52$ & $8.77 \pm 1.58$ & $5.24 \pm 3.35$ & 6938 \\
\hline $2 c^{d}$ & $3-\mathrm{OCH}_{3}$ & $2.07 \pm 0.11$ & $2.47 \pm 0.07$ & $0.91 \pm 0.08$ & $1.82 \pm 0.81$ & 51,875 \\
\hline $2 d^{e}$ & $4-\mathrm{OCH}_{3}$ & $38.1 \pm 12.4$ & $>100$ & $28.8 \pm 0.52$ & $>55.6 \pm 38.7$ & $>184$ \\
\hline $2 e^{e}$ & $3,4-\left(\mathrm{OCH}_{3}\right)_{2}$ & $2.06 \pm 0.16$ & $2.48 \pm 0.28$ & $3.61 \pm 2.50$ & $2.72 \pm 0.80$ & 56,455 \\
\hline $2 f^{d}$ & $2,5-\left(\mathrm{OCH}_{3}\right)_{2}$ & $1.29 \pm 0.60$ & $2.01 \pm 0.27$ & $0.91 \pm 0.02$ & $1.40 \pm 0.56$ & 9357 \\
\hline $2 g^{e}$ & $2,4,6-\left(\mathrm{OCH}_{3}\right)_{3}$ & $33.9 \pm 8.27$ & $48.0 \pm 10.4$ & $21.7 \pm 1.72$ & $34.5 \pm 13.2$ & 56 \\
\hline $2 h^{\mathrm{e}}$ & $3,4,5-\left(\mathrm{OCH}_{3}\right)_{3}$ & $1.13 \pm 0.79$ & $1.28 \pm 0.71$ & $0.51 \pm 0.20$ & $0.97 \pm 0.40$ & 18,875 \\
\hline $2 i^{d}$ & $3,4-\mathrm{OCH}_{2} \mathrm{O}$ & $6.35 \pm 0.12$ & $7.91 \pm 0.19$ & $34.7 \pm 12.2$ & $16.3 \pm 15.9$ & 11,043 \\
\hline $2 j^{e}$ & $2-\mathrm{F}$ & $4.40 \pm 1.32$ & $3.63 \pm 0.57$ & $2.24 \pm 1.17$ & $3.42 \pm 1.09$ & 6500 \\
\hline $2 k$ & $3-\mathrm{F}$ & $2.05 \pm 0.16$ & $2.70 \pm 0.12$ & $0.78 \pm 0.16$ & $1.84 \pm 0.98$ & 16,909 \\
\hline $21^{c}$ & $4-\mathrm{F}$ & $4.22 \pm 1.31$ & $7.07 \pm 0.47$ & $2.54 \pm 0.14$ & $4.61 \pm 2.29$ & 5415 \\
\hline $2 m$ & $3,4-\mathrm{F}_{2}$ & $1.68 \pm 0.44$ & $3.69 \pm 0.64$ & $2.04 \pm 0.97$ & $2.47 \pm 1.07$ & 34,889 \\
\hline $2 n$ & $2,6-F_{2}$ & $2.07 \pm 0.30$ & $7.46 \pm 0.38$ & $2.97 \pm 0.05$ & $4.17 \pm 2.89$ & 5552 \\
\hline 20 & $2-\mathrm{CH}_{3}$ & $5.58 \pm 0.18$ & $7.27 \pm 0.21$ & $22.8 \pm 1.85$ & $11.9 \pm 9.51$ & 2316 \\
\hline $2 p$ & $2-\mathrm{NO}_{2}$ & $1.71 \pm 0.23$ & $2.57 \pm 0.07$ & $3.82 \pm 1.14$ & $2.70 \pm 1.06$ & 5120 \\
\hline $2 q$ & $3-\mathrm{OCH}_{3}, 4-\mathrm{OH}$ & $5.76 \pm 1.20$ & $10.8 \pm 1.10$ & $8.08 \pm 8.51$ & $8.21 \pm 2.50$ & 2145 \\
\hline $2 r$ & $3-\mathrm{OH}, 4-\mathrm{OCH}_{3}$ & $2.72 \pm 0.18$ & $54.6 \pm 39.1$ & $90.7 \pm 16.2$ & $49.3 \pm 44.2$ & 64,643 \\
\hline $2 s^{e}$ & $4-\mathrm{OH}$ & $74.0 \pm 6.56$ & $>100$ & $97.3 \pm 4.62$ & $>90.4 \pm 14.3$ & $>1602$ \\
\hline $2 t^{d}$ & $3-\mathrm{OH}$ & $2.23 \pm 0.06$ & $3.45 \pm 0.30$ & $9.53 \pm 5.17$ & $5.07 \pm 3.91$ & 12,950 \\
\hline $2 u$ & $2-\mathrm{Cl}$ & $2.25 \pm 0.15$ & $5.07 \pm 1.99$ & $7.55 \pm 1.62$ & $4.96 \pm 2.65$ & 19,706 \\
\hline Doxorubicin & & $2.69 \pm 0.35$ & $>10.0$ & $>10 \pm 0.00$ & $>7.56 \pm 4.22$ & $>60,000$ \\
\hline Melphalan & & $148.0 \pm 0.68$ & $>200$ & $169 \pm 18.5$ & $>172 \pm 25.8$ & $>55$ \\
\hline
\end{tabular}

${ }^{\mathrm{a}}$ The $\mathrm{CC}_{50}$ values are the concentrations of the compounds required to kill $50 \%$ of the cells. ${ }^{\mathrm{b}}$ The letters PSE refer to the potency-selectivity expression. These figures are the product of the reciprocal of the average $C_{50}$ values against Ca9-22, HSC-2 and HSC-4 cells and the average selectivity index (SI) value multiplied by $100 .{ }^{\mathrm{c}}$ Reference [16], ${ }^{\mathrm{d}}$ Reference [7], ${ }^{\mathrm{e}}$ Reference [30].

An important issue to resolve when considering the development of these compounds is whether they demonstrate tumour-selective toxicity. Consequently, the dienones in series 2 were evaluated against human HGF, HPLF and HPC non-malignant cells, and these data are presented in Table 2. Compounds causing the least toxicity, with average $\mathrm{CC}_{50}$ values greater than $30 \mu \mathrm{M}$, are $\mathbf{2 d}\left[4-\mathrm{OCH}_{3}\right], \mathbf{2} \mathbf{g}\left[2,4,6-\left(\mathrm{OCH}_{3}\right)_{3}\right], \mathbf{2 r}\left[3-\mathrm{OH}-4-\mathrm{OCH}_{3}\right]$ and $\mathbf{2 s}[4-\mathrm{OH}]$. On the other hand, compounds causing the most toxicity with an average $\mathrm{CC}_{50}$ value of less than $2 \mu \mathrm{M}$ are $\mathbf{2 c}\left[3-\mathrm{OCH}_{3}\right], \mathbf{2 f}\left[2,5-\left(\mathrm{OCH}_{3}\right)_{2}\right], \mathbf{2} \mathbf{h}\left[3,4,5-\left(\mathrm{OCH}_{3}\right)_{3}\right]$ and $\mathbf{2 k}$ [3-F].

The next phase of the investigation was to identify those compounds which demonstrate greater toxicity to neoplasms than towards non-malignant cell lines. Under clinical conditions, neoplasms are surrounded by a variety of normal cells. Hence in order to evaluate if these compounds demonstrate tumour-selective toxicity, selectivity index (SI) figures were generated which are the quotients of the average $\mathrm{CC}_{50}$ values towards $\mathrm{HGF}$, HPLF and HPC cells and the $\mathrm{CC}_{50}$ value of the compound towards each neoplastic cell line. The data are presented in Table 1 . The results indicate that the compounds in series 2 have SI values greater than 1; hence, they demonstrate tumour-selective toxicity. The ketones with average SI figures greater than 50 are $2 \mathbf{e}\left[3,4-\left(\mathrm{OCH}_{3}\right)_{2}\right], \mathbf{2} \mathbf{i}\left[3,4-\mathrm{OCH}_{2} \mathrm{O}\right]$ and $2 \mathbf{r}\left[3-\mathrm{OH}, 4-\mathrm{OCH}_{3}\right]$ and are clearly lead molecules. In particular, $2 \mathbf{r}$ has a greater SI figure than doxorubicin. 
Two properties that are very important in evaluating candidate cytotoxins are their potencies and selective toxicities. In order to identify compounds with both of these desirable features, potency-selectivity expression (PSE) values were obtained. These figures are the products of the reciprocal of the average $C_{50}$ value towards neoplastic cells multiplied by the average SI figure times 100 . The PSE values of $\mathbf{2 a}-\mathbf{u}$ are presented in Table 2. Compounds which have PSE values over 25,000 are $\mathbf{2} \mathbf{c}, \mathbf{e}, \mathbf{m}, \mathbf{r}$. The dienone $\mathbf{2 r}$ has the highest PSE figure of 64,643 , which is 30 times greater than the value of the structural isomer 2q.

A summary of the identification of lead molecules is presented in Table 3. In particular, the 4-piperidone $\mathbf{2 r}$ is identified as a promising compound in three of the four bioevaluations.

Table 3. Identification of lead molecules based on the data in Tables 1 and 2.

\begin{tabular}{ccc}
\hline Table & Bioevaluations & Promising Compounds \\
\hline 1 & Average CC 50 values & $\mathbf{2 c}, \mathbf{h}, \mathbf{m}$ \\
1 & Average SI figures & $\mathbf{2 e}, \mathbf{i}, \mathbf{r}$ \\
2 & Low toxicity to normal cells & $\mathbf{2 d}, \mathbf{g}, \mathbf{r}, \mathbf{s}$ \\
2 & PSE & $\mathbf{2 c}, \mathbf{e}, \mathbf{m}, \mathbf{r}$ \\
\hline
\end{tabular}

The compounds in series 2 were also evaluated in a different laboratory. In this case, three human neoplastic cell lines were employed, namely, Colo205 and HT-29 colon cancers, as well as CEM leukemia cells. A non-malignant cell line, namely, human Hs27 fibroblasts, was also incorporated into the screens. The biodata generated are presented in Table 4.

Table 4. Evaluation of 2a-u towards Colo205, HT-29, CEM and Hs27 cells.

\begin{tabular}{|c|c|c|c|c|c|c|c|c|c|c|c|}
\hline \multirow[b]{3}{*}{ Compound } & \multicolumn{8}{|c|}{ Human Tumour Cell Lines } & \multicolumn{3}{|c|}{$\begin{array}{l}\text { Normal } \\
\text { Cell Line }\end{array}$} \\
\hline & & Colo205 & & HT-29 & & CEM & & Average & & Hs27 & \\
\hline & $\mathrm{R}$ & $\mathrm{CC}_{50}(\mu \mathrm{M})^{\mathrm{a}}$ & $\mathrm{SI}^{\mathrm{b}}$ & $\mathrm{CC}_{50}(\mu \mathrm{M})^{\mathrm{a}}$ & $\mathrm{SI}^{\mathrm{b}}$ & $\mathrm{CC}_{50}(\mu \mathrm{M})^{\mathrm{a}}$ & $\mathrm{SI}^{\mathrm{b}}$ & $\mathrm{CC}_{50}{ }^{\mathrm{a}}$ & $\mathrm{SI}^{\mathrm{b}}$ & $\mathrm{CC}_{50}(\mu \mathrm{M})^{\mathrm{a}}$ & $\mathrm{PSE}^{\mathrm{c}}$ \\
\hline $2 a^{d}$ & $\mathrm{H}$ & $10.7 \pm 0.05$ & 1.54 & $1.57 \pm 0.21$ & 10.5 & $9.29 \pm 0.11$ & 1.78 & 7.19 & 4.61 & $16.5 \pm 0.35$ & 64 \\
\hline $2 b$ & $2-\mathrm{OCH}_{3}$ & $1.32 \pm 0.01$ & 3.10 & $3.58 \pm 0.21$ & 1.14 & $0.82 \pm 0.09$ & 4.99 & 1.91 & 3.08 & $4.09 \pm 0.56$ & 161 \\
\hline $2 c^{e}$ & $3-\mathrm{OCH}_{3}$ & $0.32 \pm 0.11$ & 13.0 & $5.58 \pm 0.52$ & 0.75 & $4.51 \pm 0.11$ & 0.92 & 3.47 & 4.89 & $4.16 \pm 0.32$ & 141 \\
\hline $2 d^{f}$ & $4-\mathrm{OCH}_{3}$ & $14.0 \pm 0.56$ & 6.84 & $12.6 \pm 0.00$ & 7.60 & $4.45 \pm 0.03$ & 21.5 & 10.4 & 12.0 & $95.7 \pm 0.11$ & 115 \\
\hline $2 e^{f}$ & $3,4-\left(\mathrm{OCH}_{3}\right)_{2}$ & $1.36 \pm 0.17$ & 0.65 & $3.46 \pm 0.46$ & 0.25 & $0.49 \pm 0.02$ & 1.80 & 1.77 & 0.90 & $0.88 \pm 0.05$ & 51 \\
\hline $2 f^{e}$ & $2,5-\left(\mathrm{OCH}_{3}\right)_{2}$ & $0.36 \pm 0.01$ & 1.81 & $0.84 \pm 0.01$ & 0.77 & $0.42 \pm 0.02$ & 1.55 & 0.54 & 1.37 & $0.65 \pm 0.02$ & 254 \\
\hline $2 g^{f}$ & $2,4,6-\left(\mathrm{OCH}_{3}\right)_{3}$ & $16.9 \pm 0.23$ & 1.63 & $9.63 \pm 0.32$ & 2.87 & $11.0 \pm 1.06$ & 2.51 & 12.5 & 2.34 & $27.6 \pm 0.79$ & 19 \\
\hline $2 h^{f}$ & $3,4,5-\left(\mathrm{OCH}_{3}\right)_{3}$ & $0.27 \pm 0.03$ & 121 & $2.03 \pm 0.00$ & 16.1 & $0.31 \pm 0.09$ & 106 & 0.87 & 81.0 & $32.7 \pm 0.56$ & 9310 \\
\hline $2 \mathbf{i}^{\mathrm{e}}$ & $3,4-\mathrm{OCH}_{2} \mathrm{O}$ & $8.84 \pm 0.08$ & 2.17 & $7.42 \pm 1.33$ & 2.59 & $1.88 \pm 0.08$ & 10.2 & 6.05 & 4.99 & $19.2 \pm 2.38$ & 83 \\
\hline $2 j^{f}$ & $2-\mathrm{F}$ & $2.94 \pm 0.33$ & 0.68 & $3.46 \pm 0.33$ & 0.58 & $0.78 \pm 0.04$ & 2.55 & 2.39 & 1.27 & $1.99 \pm 0.17$ & 53 \\
\hline $2 \mathrm{k}$ & $3-\mathrm{F}$ & $4.19 \pm 0.15$ & 0.44 & $1.73 \pm 0.15$ & 1.06 & $0.21 \pm 0.01$ & 8.76 & 2.04 & 3.42 & $1.84 \pm 0.32$ & 168 \\
\hline $2 l^{d}$ & $4-\mathrm{F}$ & $1.56 \pm 0.28$ & 1.21 & $5.51 \pm 0.56$ & 0.34 & $1.68 \pm 0.25$ & 1.13 & 2.92 & 0.89 & $1.89 \pm 0.05$ & 31 \\
\hline $2 \mathrm{~m}$ & $3,4-\mathrm{F}_{2}$ & $1.81 \pm 0.31$ & 16.1 & $3.50 \pm 0.19$ & 8.34 & $0.58 \pm 0.05$ & 50.3 & 1.96 & 24.9 & $29.2 \pm 0.08$ & 1270 \\
\hline $2 n$ & $2,6-\mathrm{F}_{2}$ & $2.22 \pm 0.00$ & 3.50 & $7.36 \pm 0.88$ & 1.06 & $7.88 \pm 0.68$ & 0.99 & 5.82 & 1.85 & $7.77 \pm 0.89$ & 32 \\
\hline 20 & $2-\mathrm{CH}_{3}$ & $1.62 \pm 0.11$ & 30.4 & $3.54 \pm 0.42$ & 13.9 & $1.82 \pm 0.10$ & 27.1 & 2.33 & 23.8 & $49.3 \pm 0.23$ & 1022 \\
\hline $2 p$ & $2-\mathrm{NO}_{2}$ & $2.09 \pm 0.33$ & 11.6 & $2.76 \pm 0.04$ & 8.80 & $6.14 \pm 0.56$ & 3.96 & 3.66 & 8.12 & $24.3 \pm 0.11$ & 222 \\
\hline $2 q$ & $3-\mathrm{OCH}_{3}, 4-\mathrm{OH}$ & $1.73 \pm 0.15$ & 1.20 & $17.8 \pm 1.48$ & 0.12 & $1.92 \pm 0.53$ & 1.08 & 7.15 & 0.80 & $2.07 \pm 0.07$ & 11 \\
\hline $2 r$ & $3-\mathrm{OH}, 4-\mathrm{OCH}_{3}$ & $4.58 \pm 0.17$ & 2.73 & $4.26 \pm 0.01$ & 2.93 & $4.04 \pm 0.17$ & 3.09 & 4.29 & 2.92 & $12.5 \pm 1.61$ & 68 \\
\hline $2 s^{f}$ & $4-\mathrm{OH}$ & $4.17 \pm 0.32$ & 2.08 & $19.3 \pm 0.48$ & 0.45 & $1.99 \pm 0.10$ & 4.36 & 8.49 & 2.30 & $8.68 \pm 0.16$ & 27 \\
\hline $2 t^{e}$ & $3-\mathrm{OH}$ & $2.12 \pm 0.12$ & 0.64 & $4.18 \pm 0.36$ & 0.32 & $0.43 \pm 0.04$ & 3.14 & 2.24 & 1.37 & $1.35 \pm 0.08$ & 61 \\
\hline $2 u$ & $2-\mathrm{Cl}$ & $8.19 \pm 0.17$ & 0.08 & $0.89 \pm 0.07$ & 0.69 & $4.42 \pm 0.35$ & 0.14 & 4.50 & 0.30 & $0.61 \pm 0.01$ & 7 \\
\hline
\end{tabular}

${ }^{\mathrm{a}}$ The $\mathrm{CC}_{50}$ values are the concentrations of compounds required to kill $50 \%$ of the cells. ${ }^{\mathrm{b}}$ The letters SI refer to the selectivity index. The SI figures are the ratios of the $\mathrm{CC}_{50}$ values of the compounds towards non-malignant $\mathrm{HS}-27$ cells and the $\mathrm{CC}_{50}$ figures of a compound against a specific neoplastic cell line. ${ }^{\mathrm{c}}$ The letters PSE refer to the potency-selectivity expression. These figures are the product of the reciprocal of the average $\mathrm{CC}_{50}$ values against Colo205, HT-29 and CEM cells and the average SI value multiplied by 100. ${ }^{\mathrm{d}}$ Reference [16], ${ }^{\mathrm{e}}$ Reference [7],

${ }^{\mathrm{f}}$ Reference [30].

In regard to the sensitivity of the three neoplastic cell lines to the compounds in series 2 , the data in Table 4 revealed that $89 \%$ of the $\mathrm{CC}_{50}$ values are below $10 \mu \mathrm{M}, 73 \%$ are below $5 \mu \mathrm{M}$ and $21 \%$ have submicromolar $\mathrm{CC}_{50}$ values. The average $\mathrm{CC}_{50}$ values were also examined. The two most potent compounds are $2 \mathbf{f}\left[2,5-\left(\mathrm{OCH}_{3}\right)_{2}\right]$ and $\mathbf{2 h}\left[3,4,5-\left(\mathrm{OCH}_{3}\right)_{3}\right]$. The dienone $\mathbf{2} \mathbf{f}$ is 3 times more potent than the 3,4-dimethoxy analog $2 \mathbf{e}$ while $\mathbf{2 h}$ is 14 times more potent than $2 \mathrm{~g}\left[2,4,6-\left(\mathrm{OCH}_{3}\right)_{3}\right]$. 
The compounds in series 2 were also screened against Hs27 fibroblasts. The compounds with the highest $C_{50}$ values $(>25 \mu \mathrm{M})$ are $\mathbf{2} \mathbf{d}, \mathbf{g}, \mathbf{h}, \mathbf{m}, \mathbf{o}$. The data in Table 4 reveal that the dimethoxy derivatives $\mathbf{2 e}$ and $\mathbf{2} \mathbf{f}$ are highly toxic to the fibroblasts (average $\mathrm{CC}_{50}$ value of $0.77 \mu \mathrm{M}$ ), while the trimethoxy analogs $\mathbf{2 g}$, $\mathbf{h}$ are 39 times less potent (the average $\mathrm{CC}_{50}$ value of $\left.30.2 \mu \mathrm{M}\right)$. Compounds with average SI values greater than 10 are $\mathbf{2} \mathbf{d}, \mathbf{h}, \mathbf{m}, \mathbf{o}$. The large average SI value of 81.0 for $\mathbf{2 h}$ is noteworthy. The PSE values of series 2 were computed and are listed in Table 4. Three compounds have PSE figures over 1000 namely $\mathbf{2 h}, \mathbf{m}, \mathbf{o}$. Thus, a number of lead molecules are described in this study and are listed in Table 5. Thus $\mathbf{2 h}$ is a lead molecule in all four of the bioevaluations, while $\mathbf{2} \mathbf{m}$ and $\mathbf{2 o}$ are promising compounds in three of the bioassays.

Table 5. Identification of lead compounds based on the data in Table 4.

\begin{tabular}{cc}
\hline Bioevaluations & Promising Compounds \\
\hline Average CC $_{50}$ values & $\mathbf{2 f}, \mathbf{h}$ \\
Average SI values & $\mathbf{2 d}, \mathbf{h}, \mathbf{m}, \mathbf{o}$ \\
Low toxicity to normal cells & $\mathbf{2 d}, \mathbf{g}, \mathbf{h}, \mathbf{m}, \mathbf{o}$ \\
PSE & $\mathbf{2 h}, \mathbf{m}, \mathbf{o}$ \\
\hline
\end{tabular}

It is conceivable that the modes of action of $\mathbf{2} \mathbf{a}-\mathbf{u}$ towards the neoplasms are similar. In this case, the relative potencies of $\mathbf{2} \mathbf{a}-\mathbf{u}$ towards different neoplasms may be the same. In order to examine this possibility, use was made of Kendall's coefficient of concordance [31], which is a statistical method for evaluating the similarity in rank between a collection of numbers. This methodology was applied to the $\mathrm{CC}_{50}$ values of $\mathbf{2 a -} \mathbf{u}$ against Ca9-22, HSC-2 and HSC-4 malignant cells. In this case, Kendall's coefficient of concordance (W) is 0.7977, and a $p$-value of 0.0004 indicates the order of potency towards the neoplasms is the same. Since $\mathbf{2 g}, \mathbf{d}, \mathbf{s}$ are outliers, plots were made omitting $\mathbf{2 g}(\mathrm{W}=0.7668, p=0.0010), \mathbf{2 g}, \mathbf{d}$ $(\mathrm{W}=0.7400, p=0.0021)$ and $2 \mathrm{~g}, \mathbf{d}, \mathbf{s}(\mathrm{W}=0.7074, p=0.0045)$. The analysis was repeated with the $C_{50}$ values of $\mathbf{2 a - u}$ towards Colo205, HT-29 and CEM cells, which yielded a W value of $0.5834, p=0.0200$. The data generated when the outliers were removed are as follows: $\mathbf{2 g}(\mathrm{W}=0.5324, p=0.0475), \mathbf{2} \mathbf{g}, \mathbf{d}(\mathrm{W}=0.4942, p=0.0850)$ and $\mathbf{2 g}, \mathbf{d}, \mathbf{s}(\mathrm{W}=0.4788$, $p=0.1084)$. The effect of removing the outliers on the statistical results may be explained in the following ways. First, when one or more results are removed, statistical power is diminished. Second, Kendall's coefficient of concordance deals with rank and is not concerned with potency differences. For example, $\mathbf{2} \mathbf{g}$ is consistently weaker in potency compared to analogs.

In view of the relative potencies found using the Ca9-22, HSC-2 and HSC-4 assays and also using Colo205, HT29 and CEM screens, Kendall's coefficient of concordance was applied using the $\mathrm{CC}_{50}$ values of the six neoplastic cell lines. The $W$ value is 0.6086 and the $\mathrm{p}$ figure is 0.0000 . The $\mathrm{W}$ and $p$ values when outliers are systematically removed from consideration are as follows: 0.5533, 0.0000 (excluding $\mathbf{2 g}$ ), 0.5083, 0.0000 (excluding $\mathbf{2 g}$, d) and $0.4813,0.0001$ (excluding $\mathbf{2} \mathbf{g}, \mathbf{d}, \mathbf{s}$ ). This observation has two utilities. First, it provides strong evidence that the modes of action of $\mathbf{2} \mathbf{a}-\mathbf{u}$ are similar. Second, one is justified in taking the average $\mathrm{CC}_{50}$ values of each compound in the pursuit of finding correlations between cytotoxic potencies and the physicochemical properties of the aryl substituents.

An attempt was made to find one or more physicochemical parameters that influence cytotoxic properties. Hence, linear and semilogarithmic plots were made between the average $C_{50}$ values of $2 \mathbf{a}-\mathbf{u}$ and the sigma/sigma star $\left(\sigma / \sigma^{*}\right)$, pi $(\pi)$ and molecular refractivity (MR) values of the aryl substituents. These constants reflect the electronic, hydrophobic and steric properties, respectively, of the aryl groups. A summary of these results and the figures for the data generated are presented in the Supplemental Section. In a linear plot, a negative correlation was noted between the $\sigma / \sigma^{*}$ values and cytotoxic potencies $(p=0.02)$. No other correlations $(p<0.05)$ nor trends toward correlation $(p<0.10)$ were observed. Thus, potency increases as the magnitude of the electron-withdrawing properties of the aryl substituents rose. This observation may be due to the electron 
densities on the olefinic carbon atoms falling as the $\sigma / \sigma^{*}$ values rise, which increases the reactivity of the compounds towards cellular thiols, hence the extent of the cell death. Therefore, in the future, strongly electron-attracting groups should be placed in the aryl rings.

Attempts were made to find some of the ways that lead molecules exerted their cytotoxic properties. The average $\mathrm{CC}_{50}$ values of $\mathbf{2} \mathbf{a}-\mathbf{u}$ against Ca9-22, HSC-2 and HSC-4 cells are $0.70,1.16$ and $1.18 \mu \mathrm{M}$, respectively, indicating that Ca9-22 cells are more sensitive to the compounds in series 2 than are HSC-2 and HSC- 4 cells. Hence the mode of action studies used Ca9-22 cells. Two lead compounds $\mathbf{2} \mathbf{e}$ and $\mathbf{2 r}$ were chosen for bio evaluation, as these molecules display excellent cytotoxic potencies and have the best average SI and PSE figures in series 2.

Both $\mathbf{2 e}$ and $\mathbf{2} \mathbf{r}$ caused the mitotic arrest; i.e., the compounds inhibited various stages of mitosis and cell division. In contrast, a reference drug actinomycin D (AD) induced apoptotic bodies. These results are indicated in Figure 4.

A Western blot analysis was undertaken, and the results are presented in Figure 5. The enzyme poly(ADP-ribose)polymerase 1 (PARP 1) assists with the repair of damaged DNA. Thus, compounds which cleave PARP1 may be useful in cancer chemotherapy. As indicated in Figure 5, at a concentration of $3 \mu \mathrm{M}, 2 \mathbf{r}$ causes cleavage of PARP. Procaspase 3 is a precursor of caspase 3, and both of these enzymes are overexpressed in some tumours [32]. Hence reduction in the concentration of procaspase 3 and a rise in cleaved caspase 3 are useful properties for a candidate anticancer agent to demonstrate. At a concentration of $3 \mu \mathrm{M}, 2 \mathrm{r}$ causes a reduction in the concentration of procaspase 3 and, along with a concentration of $1 \mu \mathrm{M}$ of $\mathbf{2 e}$ and $\mathbf{2 r}$, shows procaspase 3 has been cleaved.

Another possible mode of action of the compounds in series $\mathbf{2}$ is their interfering with the cell cycle. The distribution of the Ca9-22 cells after treatment with $\mathbf{2 e}$ and $\mathbf{2} \mathbf{r}$ are given in Table 6 . The data indicated $\mathbf{2 e}$ and $\mathbf{2 r}$ increase the percentage of cells in the subG1 phase, which contributes to the toxic effects of these compounds.

Table 6. Cell cycle distribution of Ca9-22 cells after treatment with $\mathbf{2 e}, \mathbf{r}$.

\begin{tabular}{|c|c|c|c|c|}
\hline \multirow[t]{2}{*}{ Compound } & \multicolumn{4}{|c|}{ Distribution (\%) ${ }^{a}$} \\
\hline & SubG1 & G1 & S & $\mathrm{G} 2 / \mathrm{M}$ \\
\hline $2 \mathbf{e}(0.3 \mu \mathrm{M})$ & 2.2 & 33.1 & 20.5 & 43.7 \\
\hline $2 \mathbf{e}(1 \mu \mathrm{M})$ & $9.3 *$ & 26.1 & 14.3 & 50.2 \\
\hline $2 \mathbf{r}(1 \mu \mathrm{M})$ & $11.5^{*}$ & 18.5 & 12.0 & 57.9 \\
\hline $2 \mathbf{r}(3 \mu \mathrm{M})$ & $24.5 *$ & 35.0 & 11.4 & 29.1 \\
\hline $\mathrm{AD}(1 \mu \mathrm{M})$ & 15.6 * & 50.9 & 11.5 & 22.1 \\
\hline Control & 1.7 & 33.3 & 17.0 & 47.7 \\
\hline
\end{tabular}

Ca9-22 cells were treated for $24 \mathrm{~h}$ without (control) and with samples, and cell cycle distribution was measured. Representative cell cycle distributions in one of the triplicate samples are shown in Supplementary Figure S2. a Figures with an asterisk indicate a statistically significant difference from control $\left({ }^{*} p<0.05\right)$.

There is a lack of coplanarity between the aryl rings and the adjacent olefinic groups. These interplanar angles $\theta$ are created between two carbon atoms of the aryl rings and the olefinic groups. These $\theta$ values are caused by non-bonded interactions between the ortho protons of the aryl ring and the equatorial hydrogen atom at locations 2 and 6 of the piperidine ring [33]. Hence, by replacing the protons at positions 2 and 6 of the piperidine ring with methyl groups, substantial increases in the sizes of the theta values may occur. The cytotoxic potencies of such compounds could be compared with the analogs in series 2, which have the same aryl substituents. However, there was no reaction between 4methoxybenzaldehyde and 2,2,6,6-tetramethyl-4-piperidone when the acid catalyzation method employed in preparing series 2 was used. Under basic conditions using sodium ethoxide or sodium methoxide, a product was isolated, which was identified as 1,5-bis(4methoxyphenyl)-1,4-pentadien-3-one 3a. A possible way in which this reaction takes place is presented in Scheme 1. In order to explore the generality of this reaction, the unsubstituted, 4-chloro and 4-fluoro analogs of 3a (Figure 3)were prepared in yields of 
$22 \%$ to $41 \%$. In the future, acylation of the piperidyl nitrogen atom of 2,2,6,6-tetramethyl-4piperidone prior to attempted reactions with aryl aldehydes may lead to the formation of the desired products, since this molecular modification may prevent the opening of the piperidine ring.

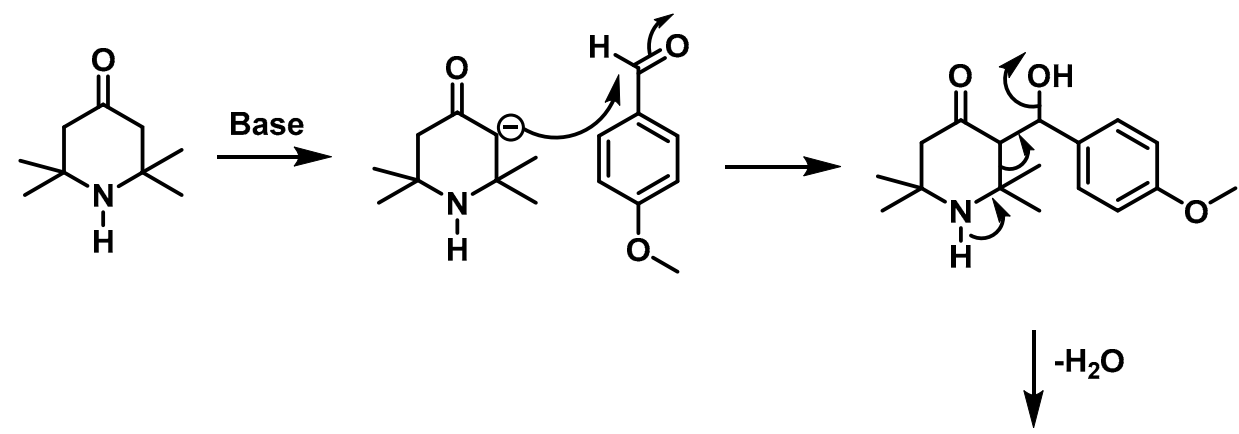<smiles>COc1ccc(/C=C/C(=O)CC(C)(C)/N=C(/C)C(=O)CC(C)(C)N=C(C)C(=O)/C=C/c2ccc(OC)cc2)cc1</smiles><smiles>COc1ccc(/C=C/C(=O)/C=C/c2ccc(OCC(C)C(C)(C)C(C)(C)C(=O)/C=C/c3ccc(OC)cc3)cc2)cc1</smiles>

Scheme 1. A possible reaction mechanism for the formation of series 3 from 2,2,6,6-tetramethyl-4piperidone and aryl aldehydes.

\section{Conclusions}

This study revealed that, in general, the compounds in series $\mathbf{2}$ are highly toxic to a range of neoplastic cells. Most of these molecules have lower toxicity to various nonmalignant cells. From these determinations, a number of lead compounds were identified. The SI and PSE values of possible lead compounds among 21 derivatives were plotted (Figure 6). This figure clearly shows that different sets of compounds showed higher tumor-specificity against different types of tumor cells: $2 \mathbf{e}$ and $2 \mathbf{r}$ for OSCC cell lines and $2 \mathrm{~h}, 2 \mathrm{~m}$ and $2 \mathrm{o}$ for colon cancer and lymphoid leukemia cell lines. It should be noted that the tumor-specificity of $\mathbf{2 e}$ and $\mathbf{2 r}(\mathrm{SI}=62.1,181)$ is comparable to that of doxorubicin $(\mathrm{SI}=78.0)$ and slightly higher than that of melphalan $(\mathrm{SI}=10.2)$ and four selected $(3 \mathrm{E}, 5 \mathrm{E})$ 3,5-bis(arylidene)-4-piperidone (BAP) derivatives $(\mathrm{SI}=12 \sim 18)$ [1].

Cytotoxic potencies increased as the electron-withdrawing properties of the aryl substituents were raised. However, the pi $(\pi)$ and MR values of the aryl groups did not affect the magnitude of the $\mathrm{CC}_{50}$ values. In the future, analogs of series 2 will be prepared in which the substituents have increased electron-withdrawing properties, e.g., the 3-nitro-4-trifluoromethyl derivative $(\Sigma \sigma=1.25$ [17]). Further attempts will be made to 
introduce methyl groups at the 2 and 6 positions of the piperidine ring and to compare their cytotoxicity with the analogs in series 2.
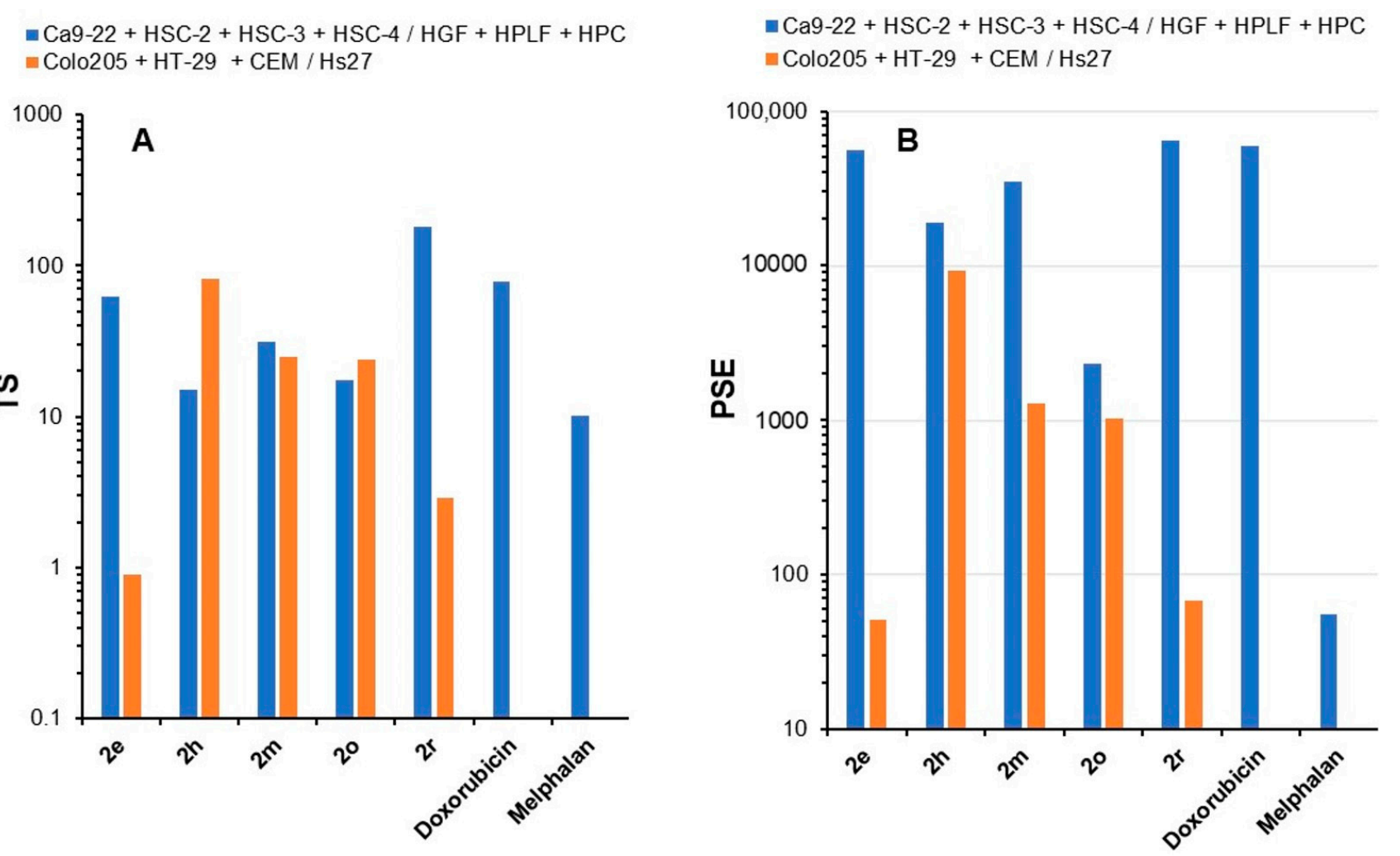

Figure 6. Comparison of SI and PSE values of 3,5-bis(benzylidene)-4-piperidones against OSCC (A) and colon and lymphoid leukemia cell lines (B). The SI and PSE values are derived from Tables 1,2 and 4. The cytotoxicity data of doxorubicin and melphalan against colon and lymphoid leukemia cell lines are not available.

Supplementary Materials: The following is available online at https:/ / www.mdpi.com/article/ $10.3390 /$ medicines $8120078 / \mathrm{s} 1,1$. Percentage yields, melting points, ${ }^{1} \mathrm{H}$ and ${ }^{13} \mathrm{C}$ NMR spectra and mass spectra of $\mathbf{2 a - u}$. 2. Percentage yields, melting points, ${ }^{1} \mathrm{H}$ NMR and mass spectra of $\mathbf{3 a - d}$ and ${ }^{13} \mathrm{C}$ NMR spectra of $\mathbf{3 b} \mathbf{b}-\mathbf{d}$. Figure S1. Raw data of full Western blot of $\mathbf{2 e}, \mathbf{r}$. Figure S2. Representative cell cycle distribution patterns in one of the triplicate samples in Table 5. 3. QSAR studies: Linear and Semilogarithmic determinations between the average $\mathrm{CC}_{50}$ values (in $\mu \mathrm{M}$ ) and various physicochemical parameters in Tables S1 and S2. Linear and Semilogarithmic plots in Figures S3-S8.

Author Contributions: Conceptualization: J.R.D., H.S., R.J.A., R.K.S. and U.D.; methodology: P.K.R., K.S., H.S., S.G.D., R.J.A., S.A., K.B., K.G.C.H. and A.Y.S.B.; supervision: J.R.D., H.S., R.J.A. and R.K.S.; writing: J.R.D., H.S., R.J.A. and P.K.R.; funding acquisition: J.R.D., H.S. and R.J.A. All authors have read and agreed to the published version of the manuscript.

Funding: This research was funded by the Maunders McNeil Foundation Inc. (J. R. Dimmock) and NIH-MARC program under Grant No.T34GM008048-35 (KCH) and was performed in facilities funded by the National Institute on Minority Health and Health Disparities (NIMHD) Grant no.5U54MD007592 to the Border Biomedical Research Center UTEP.

Institutional Review Board Statement: Ethical review and approval were waived for this study, since we have used only cell lines purchased from Riken Cell Bank and American Type Culture Collection (ATCC).

Informed Consent Statement: Not applicable since we used only cultured cells.

Data Availability Statement: Not applicable. 
Conflicts of Interest: The authors declare that they have no competing conflict of interest.

\section{References}

1. Li, N.; Xin, W.Y.; Yao, B.R.; Wang, C.H.; Cong, W.; Zhao, F.; Li, H.J.; Hou, Y.; Meng, Q.G.; Hou, G.G. Novel dissymmetric 3,5-bis(arylidene)-4-piperidones as potential antitumor agents with biological evaluation in vitro and in vivo. Eur. J. Med. Chem. 2018, 147, 21-33. [CrossRef]

2. Yousif, M.N.M.; Nassar, I.F.; Yousif, N.M.; Awad, H.M.; El-Sayed, W.A. Synthesis and anticancer activity of new substituted piperidinones linked to pyrimidine, thiazole, and triazole glycoside derivatives. Russ. J. Gen. Chem. 2019, 89, 1673-1682. [CrossRef]

3. Soliman, H.A.; Yousif, M.N.M.; Said, M.M.; Hassan, N.A.; Ali, M.M.; Award, H.M.; Abdel-Megeid, F.M.E. Synthesis of novel 1,6-naphthyridines, pyrano[3,2-c]pyridines and pyrido[4,3-d]pyrimidines derived from 2,2,6,6-tetramethylpiperidin-4-one for in vitro anticancer and antioxidant evaluation. Der Pharma Chem. 2014, 6, 394-410.

4. Kudo, C.; Yamakoshi, H.; Sato, A.; Nanjo, H.; Ohori, H.; Ishioka, C.; Iwabuchi, Y.; Shibata, H. Synthesis of 86 species of 1,5-diaryl-3-oxo1,4-pentadienes analogs of curcumin can yield a good lead in vivo. BMC Pharmacol. 2011, 11, 4. [CrossRef]

5. Pati, H.N.; Das, U.; Quail, J.W.; Kawase, M.; Sakagami, H.; Dimmock, J.R. Cytotoxic 3,5-bis(benzylidene)piperidin-4-ones and $\mathrm{N}$-acyl analogs displaying selective toxicity for malignant cells. Eur. J. Med. Chem. 2008, 43, 1-7. [CrossRef]

6. $\quad$ Singh, R.S.; Michel, D.; Das, U.; Dimmock, J.R.; Alcorn, J. Cytotoxic 1,5-diaryl-3-oxo-1,5-pentadienes: An assessment and comparison of membrane permeability using Caco-2 and MDCK monolayers. Bioorganic Med. Chem. Lett. 2014, 24, 5199-5202. [CrossRef] [PubMed]

7. Gregory, M.; Dandavati, A.; Lee, M.; Tzou, S.; Savagian, M.; Brien, K.A.; Satam, V.; Patil, P.; Lee, M. Synthesis, cytotoxicity, and structure-activity insight of N-H and N-methyl-3,5-bis-(arylidenyl)-4-piperidones. Med. Chem. Res. 2013, 22, 5588-5597. [CrossRef]

8. Fawzy, I.M.; Youssef, K.M.; Ismail, N.S.; Gullbo, J.; Abouzid, K.A. Newly designed and synthesized curcumin analogs with in vitro cytotoxicity and tubulin polymerization activity. Chem. Biol. Drug Des. 2015, 86, 80-90. [CrossRef] [PubMed]

9. Eryanti, Y.; Hendra, R.; Herlina, T.; Zamri, A.; Supratman, U. Synthesis of curcumin analogue, N-H and N-benzil-4-piperidone and their cytotoxic activity. Procedia Chem. 2015, 17, 224-229. [CrossRef]

10. Hossain, M.; Das, S.; Das, U.; Doroudi, A.; Zhu, J.; Dimmock, J.R. Novel hybrid molecules of 3,5-bis(benzylidene)-4-piperidones and dichloroacetic acid which demonstrate potent tumour-selective cytotoxicity. Bioorganic Med. Chem. Lett. 2020, $30,126878$. [CrossRef] [PubMed]

11. Sakagami, H.; Watanabe, T.; Hoshino, T.; Suda, N.; Mori, K.; Yasui, T.; Yamauchi, N.; Kashiwagi, H.; Gomi, T.; Oizumi, T.; et al Recent progress of basic studies of natural products and their dental application. Medicines 2019, 6, 4. [CrossRef] [PubMed]

12. Sakagami, H.; Tomomura, M. Dental application of natural products. Medicines 2018, 5, 21. [CrossRef]

13. Maydt, D.; De Spirt, S.; Muschelknautz, C.; Stahl, W.; Muller, T.J.J. Chemical and biological activity of chalcones and other $\alpha, \beta$-unsaturated carbonyl compounds. Xenobiotica 2013, 43, 711-718. [CrossRef]

14. Mutus, B.; Wagner, J.D.; Talpas, C.J.; Dimmock, J.R.; Phillips, O.A.; Reid, R.S. 1-p-Chlorophenyl-4,4-dimethyl-5-diethylamino-1penten-3-one hydrobromide, a sulfyhydryl-specific compound which reacts irreversibly with protein thiols but reversibly with small molecular weight thiols. Anal. Biochem. 1989, 177, 237-243. [CrossRef]

15. Xu, Y.; Kalyanaraman, B. Synthesis and ESR studies of novel cyclic nitrone spin trap attached to a phosphonium group-A suitable trap for mitochondria-generated ROS? Free Radic. Res. 2007, 41, 1-7. [CrossRef] [PubMed]

16. Dimmock, J.R.; Padmanilayam, M.P.; Puthucode, R.N.; Nazarali, A.J.; Motaganahalli, N.L.; Zello, G.A.; Quail, J.W.; Oloo, E.O.; Kraatz, H.B.; Prisciak, J.S. A conformational and structure-activity relationship study of cytotoxic 3,5-bis(arylidene)-4-piperidones and related $N$-acryloyl analogues. J. Med. Chem. 2001, 44, 586-593. [CrossRef]

17. Hansch, C.; Leo, A.J. Substituent Constants for Correlation Analysis in Chemistry and Biology; John Wiley and Sons: New York, NY, USA, 1979; p. 49.

18. Taft, R.W., Jr. Separation of polar, steric and resonance effects in reactivity. In Steric Effects in Organic Chemistry; Newman, M.S., Ed.; John Wiley and Sons: New York, NY, USA, 1956; p. 591.

19. Structural Package for Social Sciences, SPSS for Windows; Release 26.0; SPSS: Chicago, IL, USA, 2008.

20. Takao, K.; Hoshi, K.; Sakagami, H.; Shi, H.; Bandow, K.; Nagai, J.; Uesawa, Y.; Tomomura, A.; Tomomura, M.; Sugita, Y. Further quantitative structure-cytotoxicity relationship analysis of 3-styrylchromones. Anticancer Res. 2020, 40, 87-95. [CrossRef]

21. Sakagami, H.; Okudaira, N.; Masuda, Y.; Amano, O.; Yokose, S.; Kanda, Y.; Suguro, M.; Natori, T.; Oizumi, H.; Oizumi, T. Induction of apoptosis in human oral keratinocyte by doxorubicin. Anticancer Res. 2017, 37, 1023-1029.

22. Sugita, Y.; Takao, K.; Uesawa, Y.; Nagai, J.; Iijima, Y.; Sano, M.; Sakagami, H. Development of newly synthesized chromone derivatives with high tumor specificity against human oral squamous cell carcinoma. Medicines 2020, 7, 50. [CrossRef] [PubMed]

23. Lema, C.; Varela-Ramirez, A.; Aguilera, R.J. Differential nuclear staining assay for high-throughput screening to identify cytotoxic compounds. Curr. Cell Biochem. 2011, 1, 1-14.

24. Santiago-Vázquez, Y.; Das, U.; Varela-Ramirez, A.; Baca, S.T.; Ayala-Marin, Y.; Lema, C.; Das, S.; Baryyan, A.; Dimmock, J.R.; Aguilera, R.J. Tumor-selective cytotoxicity of a novel pentadiene analogue on human leukemia/lymphoma cells. Clin. Cancer Drugs 2016, 3, 138-146. [CrossRef] 
25. Varela-Ramirez, A.; Costanzo, M.; Carrasco, Y.P.; Pannell, K.H.; Aguilera, R.J. Cytotoxic effects of two organotin compounds and their mode of inflicting cell death on four mammalian cancer cells. Cell. Biol. Toxicol. 2011, 27, 159-168. [CrossRef] [PubMed]

26. Sakagami, H.; Furukawa, T.; Satoh, K.; Amano, S.; Iijima, Y.; Koshikawa, T.; Asai, D.; Fukuchi, K.; Takemura, H.; Kanamoto, T.; et al. Re-evaluation of chemotherapeutic potential of pyoktanin blue. Medicines 2021, 8, 33. [CrossRef]

27. Yamali, C.; Sakagami, H.; Uesawa, Y.; Kurosaki, K.; Satoh, K.; Masuda, Y.; Yokose, S.; Ece, A.; Bua, S.; Angeli, A.; et al. Comprehensive study on potent and selective carbonic anhydrase inhibitors: Synthesis, bioactivities and molecular modelling studies of 4-(3-(2-arylidenehydrazine-1-carbonyl)-5-(thiophen-2-yl)-1H-pyrazole-1-yl) benzenesulfonamides. Eur. J. Med. Chem. 2021, 217, 113351. [CrossRef]

28. Contreras, L.; Calderon, R.J.; Varela-Ramirez, A.; Zhang, H.-Y.; Quan, Y.; Das, U.; Dimmock, J.R.; Skouta, R.; Aguilera, R.J. Induction of apoptosis via proteasome inhibition in leukemia/lymphoma cells by two potent piperidones. Cell. Oncol. 2018, 41, 628-636. [CrossRef]

29. Das, S.; Das, U.; Michel, D.; Gorecki, D.K.J.; Dimmock, J.R. Novel bis(arylidene)-4-piperidone dimers: Potent cytotoxins against colon cancer cells. Eur. J. Med. Chem. 2013, 64, 321-328. [CrossRef]

30. Wu, J.; Zhang, Y.; Cai, Y.; Wang, J.; Weng, B.; Tang, Q.; Chen, X.; Pan, Z.; Liang, G.; Yang, S. Discovery and evaluation of piperid-4-one-containing mono-carbonyl analogs of curcumin as anti-inflammatory agents. Bioorganic Med. Chem. 2013, 21, 3058-3065. [CrossRef] [PubMed]

31. Sheshkin, D. Handbook of Parametric and Nonparametric Statistical Procedures; Chapman and Hall: London, UK, 2004; pp. 1093-1107.

32. Boudreau, M.W.; Peh, J.; Hergenrother, P.J. Procaspase-3 overexpression in cancer: A paradoxical observation with therapeutic potential. ACS Chem. Biol. 2019, 14, 2335-2348. [CrossRef]

33. Dimmock, J.R.; Arora, V.K.; Wonko, S.L.; Hamon, N.W.; Quail, J.W.; Jia, Z.; Warrington, R.C.; Fang, W.D.; Lee, J.S. 3,5-bisbenzylidene-4-piperidones and related compounds with high activity towards P388 leukemia cells. Drug Des. Deliv. 1990, 6, 183-194. [PubMed] 